\title{
BLOOD DONATIONS AS COSTLY SIGNALS OF DONOR QUALITY
}

\author{
H. F. LYLE III ${ }^{* 1}$, E. A. SMITH ${ }^{1}$, R. J. SULLIVAN ${ }^{2}$ \\ ${ }^{1}$ Department of Anthropology, University of Washington, Seattle \\ ${ }^{2}$ Department of Anthropology, California State University, Sacramento; \\ Department of Psychiatry and Behavioral Sciences, School of Medicine, \\ University of California, Davis
}

\begin{abstract}
This is the first empirical investigation of blood donations in evolutionary perspective. We examine blood donor and non-donor attitudes about health and injury risks, donor characteristics, and the social value of donor participation. We propose that blood donations may communicate qualities about donors to third parties. Observers may benefit from information about the donor's health, value as a reciprocal partner, and/or ability to endure what is perceived as an anxiety-provoking and risky experience. Donors may benefit from an enhanced reputation, which can lead to greater access to cooperative networks and high-quality partners. We found that participants recognized the need for blood and perceived blood donors as generous and healthy. Study results indicated that anxiety and the perceived risk of a negative health consequence dramatically affected the willingness of donors and non-donors to donate blood in the future. These findings support our hypothesis that the act of blood donation may signal adaptive information about donor quality to third parties.
\end{abstract}

Keywords: unconditional generosity, costly signaling theory, blood donations

\section{INTRODUCTION}

Social scientists and public health experts have long considered non-remunerative blood donations to be examples of unalloyed altruism. Such apparently pure generosity among strangers is rare and findings from research attempting to pin down the motivations for donation to alleviate the chronic shortages of clinical blood supplies

\footnotetext{
*Corresponding author: HENRY F. LYLE III, Department of Anthropology, Box 353100, University of Washington, Seattle, WA 98195-3100, Cell: (206) 947-9594, Office: (206) 543-8007, Fax: (206) 543-3285, E-mail: lyle3@u.washington.edu
} 
have remained enigmatic and contradictory (TITMUSS 1971; FERNANDEZMONTOYA 1997; RAPPORT and MAGGS 2002; HUPFER 2006).

The evolutionary puzzle posed by blood donation was noted by DAWKINS (1976) in his classic The Selfish Gene. Dawkins wrote "[m]aybe I am naïve, but I find myself tempted to see [blood donations] as a genuine case of pure, disinterested altruism" (1976: 230), a view matching the conventional wisdom found in the clinical literature (TITMUSS 1971; FERNANDEZ-MONTOYA 1997). Surprisingly, the issue Dawkins raised has not been followed up by researchers interested in the evolution of cooperation, and to our knowledge this initial analysis is the first study investigating the puzzle of blood donations from an evolutionary perspective.

There are several characteristics of blood donation that make the phenomenon inherently interesting:

1) The blood distribution system is amenable to "free riding" because those who receive a blood transfusion are not required to provide blood in return. For instance, while most Americans will undergo a procedure that requires donated blood, only 5\% actually donate (PILIAVIN and CALLERO 1991; GLYNN et al. 2006).

2) A blood donor is not guaranteed a blood transfusion if he or she (or a family member) needs a transfusion in the future.

3) In the U.S. and elsewhere it is illegal to receive monetary or other forms of compensation for a whole blood donation.

Thus, donating blood poses an evolutionary conundrum: Why incur costs to provide a highly valuable resource to unrelated strangers, most of whom are nonreciprocators? Cultural norms of community service and aiding the needy may account for some donations, but these are proximate explanations that do not fully explain the dynamics of blood sharing, including frequent donation shortfalls, failure of most people to donate, and the use of varied incentives designed to attract donors. Neither is direct reciprocity plausible, given equal access of non-donors to blood and the size of the social networks involved. Accordingly, we propose that blood donors may receive an indirect benefit which outweighs the cost of donation.

Specifically, we draw on costly signaling theory to propose that blood donation provides a plausible vehicle for honest communication about aspects of donor quality. In this paper, we examine key prerequisites for blood donation as a costly signal: that blood donors are perceived as generous and healthy, and that the perceived costs of donating influences one's willingness to give a future donation. In considering these conditions, we focus on attitudes about blood donations among a sample of young adults. We consider only purely voluntary, non-remunerative blood donations where the donor has no control over its destination.

\section{Costly signaling theory}

Costly signaling theory has received considerable attention in recent years and is proving to be a powerful tool for solving evolutionary puzzles such as risk taking 
(NeLl 2002; FARTHING 2005; WiLKE et al. 2006) and unconditional generosity (SOSIS 2000; BLIEGE BIRD and SMITH 2005). From the perspective of signaling theory, "altruism" (unconditional generosity) is a multidimensional signal that can honestly broadcast one's cooperative intent and ability (GURVEN et al. 2000; GINTIS, SMITH and BOWLES 2001; BARCLAY and WILLER 2007), economic status (VEBLEN 1899; BOONE 1998), trustworthiness (BERECZKEI, BIRKAS, and KEREKES 2007; BERGSTROM, KeRR and LACHMANN 2008) and physical vitality (SMITH, BLIEGE BIRD and BIRD 2003) to potential mates and/or current or prospective reciprocal partners.

The key question addressed by signaling theory is: What factors can ensure honest communication given that individuals rarely have completely coincident interests? Some signals are honest because they simply cannot be faked. For example, when marking territorial boundaries tigers signal their physical size by scratching tree trunks as high as they can reach. Biologists term such signals "indexical" (MAYNARD SMITH and HARPER 2003). In a broader and more interesting class of signals, honesty is ensured by a linkage between signal cost and an underlying quality of the signaler (JOHNSTONE 1997). Thus, costly signals (such as wasteful expenditure of resources) send a reliable message about the signaler's ability to incur the cost of the signal (VEBLEN 1899; SPENCE 1973; ZAHAVI 1975; GRAFEN 1990). The signal can be faked by low-quality individuals, but these signalers pay a higher signal cost, and thus will receive a lower net benefit (GRAFEN 1990; BLIEGE BIRD and SMITH 2005). Venues for signaling should clearly show differences in quality between participants that are otherwise not easily observable. Both signalers and signal receivers benefit from the transaction. Signal receivers benefit from the adaptive information that the signal provides, while signalers potentially benefit from the reputation they establish via the signal.

Veblen (1899) first explained how conspicuously consuming material items can be a form of social competition that reliably signals an individual's wealth. A public donation is a form of conspicuous consumption whereby the donor displays his or her wealth by transferring money or goods to a collective recipient, such as a charity organization. This kind of competitive altruism, termed conspicuous donations by ZAHAVI and ZAHAVI (1997), can enhance one's reputation among peers, intimidate competitors, and attract mates (SMITH and BLIEGE BIRD 2000). Whereas the Veblenian model views donor generosity as simply the cost of the signal, it is also possible to interpret a conspicuous act of generosity as an "altruistic message" that reliably broadcasts the signaler's willingness and ability to share (GURVEN et al. 2000; GinTis, SMith and BOWLes 2001; SMith and Bliege BiRD 2005). When making decisions about who to trust and/or with whom to form a long-term cooperative partnership, humans are often faced with imperfect and misleading information. Signaling arenas that involve costly acts of generosity provide a means for honest communication about the quality of signalers as reciprocal partners (RoBERTS 1998; GINTIS, SMITH and BOWLES 2001). Signalers benefit from special access to cooperative social networks and greater cooperation within these networks 
(MilinSKi, SEMmANn and KRAMBecK 2002; BARClay and WiLler 2007). Signaling a capacity to share can also reassure current sharing relationships, increase the likelihood of reciprocation in times of need, and attract mates (ROBERTS 1998; GuRVEN et al. 2000; KeLly and DunBar 2001; SMITH and Bliege BiRD 2005; FARRELLY, LAZARUS and ROBERTS 2007).

In addition to signaling cooperative intent, a blood donation can send important information about other qualities, such as the donor's health status and ability to withstand the possible consequences of risks. A wide range of species have evolved physiological mechanisms that honestly advertise an individual's health status (GETTY 2002; WAITT et al. 2003; LOYAU et al. 2005). Since many people are ineligible to donate blood due to health problems and disease status, knowledge that a person is a blood donor provides a "health profile" of the donor to observers. Giving blood may further signal a willingness to engage in risky and anxiety-provoking situations. A wealth of research shows that young adults will engage in risky behavior as a means to signal underlying qualities (WILSON and DALY 1985; BYRNE, MiLleR and SCHAFER 1999; DALY and WILSON 2001; FARTHING 2005; WILKE et al. 2006; LYLE and SULLIVAN 2007).

\section{Costs and benefits of donating blood}

In the United States and EU member states, remunerative donations are not allowed because compensated donors are more likely to carry transmissible diseases (FERNANDEZ-MONTOYA 1997). The frequency of transmitted diseases has decreased with the move to a non-remunerative system, but so too has the frequency of blood donations. Despite major campaigns to recruit donors and decades of research on donor motivation, blood shortages remain a worldwide phenomenon (ANDROULAKI et al. 2005). Additionally, while the need for blood is increasing in the U.S., the current blood supply is barely meeting demand (GLYNN et al. 2002; SCHREIBER et al. 2006)

Researchers interested in why few people donate blood have collected a wealth of data on the perceived costs and risks of donating blood. A variety of perceived costs and risks, including fear of negative health consequences, anxiety about needles, anxiety about mistakes by staff and lost time has been shown to affect one's willingness to donate. These perceptions have been observed across cultures that differ economically and socially, including Bangladesh (HOSAIN, ANISSUZZAM and BEgUM 1997), Thailand (WIWANITKIT 2002), Spain (FERNANDEZ-MonTOYA 1997), Scotland (ROBERTSON and MCQUEEN 1994), the U.S (PILIAVIN and CALlERO 1991) and Nigeria (OlAIYA et al. 2004). Further concerns about side effects such as weight loss, sexual failure, high blood pressure, dizziness, pain, bruising, nausea, faintness, fever, convulsion, and sudden death have been documented (OlAiYA et al. 2004; HUPFER, TAYLOR and LETWIN 2005). Donation trauma has been shown to be the most negative factor anticipated by both prospective and re- 
peat donors (HUPFER, TAYLOR and LETWIN 2005). These costs may explain why only half of those who donate blood for the first time ever return for a second donation (GLYNN et al. 2002).

Although blood donations appear to be examples of pure altruism, donors may receive personal benefits. Blood donations are distinctive in being a renewable resource that is in great demand. Consequently, blood donations provide an ideal means to repeatedly demonstrate generosity. Some blood collection centers in the US employ programs that offer blood points in return for a blood donation, which can be used to "purchase" practical and leisurely items at the center's store. Some blood centers also offer blood vouchers, which allows a donor to "store" blood in the form of a credit that can be applied toward a blood transfusion if needed in the future by the donor or the donor's friends and family. Research indicates that these incentives strongly encourage current and prospective donors, and we will discuss the evolutionary significance of these incentives elsewhere (LYLE, SMITH, and SULLIVAN, unpublished data). The present paper focuses on the reputational benefits of blood donation by investigating a blood sharing milieu where blood points, blood vouchers and other incentives are not offered.

We do not know whether blood donors gain a net fitness benefit (and are thus behaving in a currently adaptive manner) or are executing adaptations that were selected in past environments when social groups were small and intimate, and are currently not adaptive. We return to this issue in the Conclusion section.

\section{BLOOD DONATION AS COSTLY SIGNALS: PREDICTIONS}

In light of the theory and prior research discussed here, we propose several hypotheses regarding blood donation as a signaling system. Our predictions focus on four aspects of this hypothesized system: (1) blood donors (signalers) experience lower costs with regard to expected risk, inconvenience, and anxiety; (2) the perceived costs of making a donation affects one's willingness to donate blood, such that those who perceive greater costs will have a lower stated likelihood of future donation; (3) blood donation is considered an act of generosity; and (4) blood donors are perceived as healthy.

\section{Do the perceived costs of donating affect one's willingness to share?}

If the perceived cost of donating blood affects one's willingness to share, then nondonors should perceive greater costs in blood donation than donors. (1) Thus, we predict that non-donors are more concerned about (a) the risk of a negative health consequence, (b) the inconvenience and time lost, and (c) the fear and anxiety related to giving a blood donation. Furthermore, we expect that as the perceived costs of donating increases, the likelihood of giving a future donation decreases. (2) Therefore, we predict a negative relationship between one's willingness to donate 
blood in the future and each of the following perceived costs: (a) risk of a negative health consequence, (b) inconvenience and time lost, and (c) fear and anxiety of giving a blood donation. We focus on perceived costs (rather than objectively measured ones) for two reasons: first, data on the former are much more readily collected; second, anxiety, fear, and aversion to physical risks will correlate with reduced ability to handle emergencies and risks that arise unexpectedly, making such individuals less useful as allies or mates (all else being equal).

\section{Are blood donors perceived as generous?}

A signal has no value if there is no audience (HAWKES and BLIEGE BIRD 2002). If donating blood is indeed a signal of generosity that is socially valued, we would expect observers to recognize this. (3) We predict that observers (in effect, non-donors and donors in our study sample) will (a) recognize that there is a need for blood (i.e., that donation is a social good) and (b) perceive a blood donation as an act of generosity.

\section{Are blood donors perceived as healthy and disease-free?}

Given our assumption that blood donation is a signal of the donor's health and disease status, (4) we predict that both donors and non-donors will perceive donors as relatively disease-free and healthy.

\section{METHODS}

Institutional review board approval was acquired from the University of Washington (UW). The study population $(N=346)$ was comprised of anthropology and business undergraduate students from UW, Seattle and UW, Tacoma. Participants were offered extra credit for taking an online survey instrument. Ninety-three percent of those recruited completed at least part of the survey. Eleven participants were excluded for submitting incomplete surveys. The average age of the participants was 20.1 years $(\mathrm{SD}=3.57)$; $71 \%(n=245)$ were female and $29 \%$ were male $(n=101)$. Donors $(n=119)$ were classified as those who had donated blood at least once. Thirty-four percent $(n=119)$ of those who participated had donated blood at least once and $66 \%$ had never donated blood $(n=227)$.

A pilot survey instrument was developed from unstructured interviews with blood donors and non-donors. The pilot survey was tested $(n=12)$ for item clarity and coherence. The validity of the pilot research and test instrument development was assessed by subjecting the questionnaire data to a Principal Components Analysis (Table 1), which is discussed in more detail below. The final online survey instrument was composed of three dimensions: perceived cost of donating, perceived generosity of blood donors, and perceived health status of donors. The per- 
ceived cost of donating was measured using three clusters of items: risk of a negative health consequence, pain and anxiety, and inconvenience and time wasted ( $\mathrm{Ta}$ ble 2). The perceived generosity of blood donors was measured using two groups of items: perception of blood donors and perceived need for blood (Table 3). The final group of items measured the perceived health status of donors (Table 4). The perceptions of blood donations and donors were measured using a five-point Likert scale: (5) strongly agree, (4) agree, (3) undecided, (2) disagree, and (1) strongly disagree.

The survey instrument included other Likert-style items that measured the overall perceived costs of giving a blood donation $(1=$ very low to $5=$ very high $)$ regarding risk, inconvenience, and anxiety, as well as the likelihood a participant would make a future donation ( $1=$ highly unlikely to $5=$ highly likely). It also assayed eligibility status, knowledge of someone who has received a transfusion, and if donors had donated blood on a UW campus. The survey concluded with an openended question that allowed participants to provide additional comments about their perspective regarding blood donations.

For descriptive purposes, item cluster distributions for the perceived costs of giving a blood donation, perceived generosity and health of donors, and the perceived need for blood are presented using 95th-percentile confidence intervals (Figs. 1 and 2). Relationships between ranked dependent variables and fixed factors were analyzed using the Mann-Whitney test. The predictive relationships between the overall perceived costs of giving a blood donation (risk, inconvenience, and anxiety) and the likelihood of giving a future donation was assayed using Somers' $d$ statistic. Hypotheses involving Likert scales call for non-parametric tests. For the items in Tables 2, 3, and 4, we employed a method which formulates two categories of responses: "agree" and "strongly agree" responses are combined to form one category and "disagree" and "strongly disagree" responses are combined to form another category. Responses to the midpoint of the scale (undecided) are treated as missing data. Using this method, an agree:disagree ratio can be quantified for individual items and complete item clusters. We ran one-sample chi-square tests of proportions (with a predicted proportion of 0.5 ) to determine if donors were perceived as generous and healthy, and to see if the need for blood was recognized. The proportion 0.5 represents the null hypotheses: people are indifferent regarding the need for blood, and indifferent regarding blood donors as generous and healthy. This analysis was run on individual items in Tables 3 and 4, as well as the complete item clusters "Perception of donors", Perception of need", and "Health Status". Those items that are thematically reversed - see (-) items in Tables 3 and 4 - were corrected (i.e., "agree: responses were coded as "disagree" and vice versa) prior to analysis. All tests are two-tailed at the 0.05 level of significance. Statistical tests were conducted using SPSS 16.

The 5-point Likert-type variables answered by all study participants were included in a Principal Component Analysis (see Tables 2, 3, and 4). Varimax rotation produced eight components with eigenvalues $>1$ accounting for $52.5 \%$ of the 
total variance (Table 1). The extracted components generally follow the designed questionnaire item clusters of "risk of a negative health consequence", "time and inconvenience", "pain and anxiety", "perception of donors", "perception of need for blood", and "health status signal" but with some residual variance, particularly in component 8. Overall, the extracted factors closely approximate the questionnaire design and indicate that the underlying structure of the instrument is appropriate and will form a solid basis for further development and research.

Table 1. Principal Components Analysis N = 346 (see Tables 2, 3, and 4).

\begin{tabular}{|c|c|c|c|c|c|c|c|c|}
\hline \multirow{2}{*}{ Factor/Items } & \multicolumn{8}{|c|}{ Varimax Rotated Component Loadings* } \\
\hline & 1 & 2 & 3 & 4 & 5 & 6 & 7 & 8 \\
\hline $\begin{array}{l}\text { Risk of negative health conse- } \\
\text { quence }\end{array}$ & & & & & & & & \\
\hline Negative health consequences 4 & .755 & & & & & & & \\
\hline Negative health consequences 6 & .721 & & & & & & & \\
\hline Negative health consequences 1 & -.587 & & & & & & .327 & \\
\hline Negative health consequences 3 & .465 & & & & & & & \\
\hline Perception of donors & & & & & & & & \\
\hline Perception of donors 4 & & .744 & & & & & & \\
\hline Perception of donors 6 & & .713 & & & & & & \\
\hline Perception of donors 5 & & .664 & & & & & & \\
\hline Perception of donors 2 & & -.414 & & & & & .306 & .376 \\
\hline Perception of donors 1 & & .346 & & 339 & & & & \\
\hline Time and inconvenience & & & & & & & & \\
\hline Time and inconvenience 2 & & & -.722 & & & & & \\
\hline Time and inconvenience 1 & & & .635 & & & & & \\
\hline Time and inconvenience 4 & & & .580 & & & & .365 & \\
\hline Time and inconvenience 3 & & & -.486 & & & & & .341 \\
\hline Perception of need for blood & & & & & & & & \\
\hline Perception of need for blood 3 & & & & -.737 & & & & \\
\hline Perception of need for blood 4 & & & & .721 & & & & \\
\hline Perception of need for blood 1 & & & & .649 & & & & \\
\hline Perception of donors 3 & & & & .473 & & & & \\
\hline
\end{tabular}


Table 1. (continued)

\begin{tabular}{|c|c|c|c|c|c|c|c|c|}
\hline \multirow{2}{*}{ Factor/Items } & \multicolumn{8}{|c|}{ Varimax Rotated Component Loadings* } \\
\hline & 1 & 2 & 3 & 4 & 5 & 6 & 7 & 8 \\
\hline \multicolumn{9}{|l|}{ Pain and anxiety } \\
\hline Pain and anxiety 2 & & & & & .617 & & & \\
\hline Pain and anxiety 3 & & & -.311 & & .602 & & & \\
\hline Pain and anxiety 1 & & & .386 & & -.523 & & & \\
\hline Pain and anxiety 4 & & & & & -.497 & & & \\
\hline \multicolumn{9}{|l|}{ Health status signal } \\
\hline Health 3 & & & & & & .787 & & \\
\hline Health 2 & & & & & & .645 & & \\
\hline Health 1 & & & & & .302 & .636 & & \\
\hline \multicolumn{9}{|l|}{ Residual Risk } \\
\hline Negative health consequence 2 & -.304 & & & & & & .678 & \\
\hline Health 4 & & & & & & .407 & .491 & \\
\hline Negative health consequence 5 & & & .350 & & & & .490 & \\
\hline \multicolumn{9}{|l|}{ Residual Need } \\
\hline Need for blood 2 & & & & & & & & .809 \\
\hline Eigenvalue & 3.395 & 2.443 & 1.783 & 1.673 & 1.564 & 1.410 & 1.340 & 1.081 \\
\hline Initial Variance & 12.123 & 8.725 & 6.368 & 5.975 & 5.584 & 5.035 & 4.785 & 3.862 \\
\hline
\end{tabular}

*Loadings $<0.3$ are not shown

Reliability analysis of our psychometric instrument indicates unidimensionality in the principal constructs. Cronbach's alpha levels were acceptable for the "cost" measure $(N=14 ; \alpha=0.69)$ and "generosity" measure $(N=10 ; \alpha=0.62)$ (Tables 2 and 3). The third measure, perceived health status, yielded a low but acceptable alpha value $(N=4 ; \alpha=0.52)$ given the small number of items it contained (Table 4).

Because of the disproportionately high number of females in our sample, we tested to see if the opinions of females were driving the means for "all participants" reported in Tables 2, 3, and 4. To do so, we selected a random sample of females that was equal to the number of males in our sample $(n=101)$ and reran the analysis with equal numbers of males and females. We repeated this method for three tries and each time the means for all participants in the selected sample $(n=202)$ fell within the 95\% CI of the means for all participants reported in Tables 2, 3, and $4(n=346)$. 


\section{RESULTS}

\section{The perceived cost of donating blood affects one's willingness to donate}

We predicted (1a-1c) that blood donors would perceive blood donations as being less costly compared with non-donors. In addition to the items that assayed the perceived risk/inconvenience/anxiety associated with giving a blood donation (see $\mathrm{Ta}$ ble 2), the survey also included three items in which participants ranked "overall" how risky, inconvenient, and anxiety-provoking giving a blood donation is on a 5 point scale ( $1=$ very low to 5 = very high). There were significant differences between donors and non-donors regarding the perceived risk of a negative health consequence (Mann-Whitney test; $Z=-3.46 ; n=227,119 ; p=0.001$ ) and anxiety (Mann-Whitney test; $Z=-6.24 ; n=227,119 ; p<0.001$ ), but no difference regarding the time and inconvenience of donating blood (Mann-Whitney test; $Z=-0.104$; $n=227,119 ; p=0.917)$. The items in Table 2 that concern specific aspects of each costs show a similar pattern. Consistent with the results reported above, there were significant differences in multiple "risk of a negative health consequence" and "anxiety" items, but no significant differences between donors and non-donors for any "time and inconvenience" item (Table 2). Thus, using multiple measures, our predictions that blood donors are less concerned about the "risk" and "anxiety" costs of a blood donation were supported, however, we found no difference with regard to perceived "time" cost. We also predicted a negative relationship between each of the perceived costs of donating blood $(1=$ very low to $5=$ very high) and the stated likelihood of future donation ( $1=$ highly unlikely to $5=$ highly likely). We found a significant negative relationship between the perceived risk of a negative health consequence and the likelihood of a future donation. (Somers' $d=-0.229, p<0.001$ ). A similar relationship was found for anxiety (Somers' $d=-0.345, p<0.001$ ). Although there was a negative relationship between the perceived costs in terms of time and inconvenience and the reported likelihood of giving a future donation, the association was weaker and fell short of statistical significance (Somers' $d=-0.084, p=0.092$ ). Additionally, we ran separate analyses of donors and non-donors and found similar relationships between perceived costs and likelihood of a future donation as reported above.

The item cluster distributions indicate that both donors and non-donors are most concerned about the anticipated pain and anxiety of giving a blood donation, though blood donors are considerably less concerned than non-donors (Fig. 1). Non-donors are more concerned about the risk of a negative health consequence than donors, while there is little difference regarding the perceived time wasted and inconvenience of giving a blood donation between donors and non-donors (Fig. 1). 
Table 2. Survey responses for statements concerning blood donation costs ( $5=$ strongly agree, 4 = agree, 3 = uncertain, 2 = disagree, 1 = strongly disagree). Mean rank scores, $S D$ and $Z$ statistics (derived from the Wilcoxon-Mann-Whitney test) are reported.

\begin{tabular}{|c|c|c|c|c|}
\hline \multirow[t]{2}{*}{ Cost items $^{\mathrm{a}}$} & $\begin{array}{c}\text { All } \\
\text { participants }\end{array}$ & Donors & Non-donors & $Z$ statistic $^{\mathrm{b}}$ \\
\hline & $N=346$ & $N=119$ & \multicolumn{2}{|l|}{$N=227$} \\
\hline \multicolumn{5}{|l|}{ Risk of negative health consequences } \\
\hline 1. Donating blood is risk-free. $(-)$ & $3.18(.925)$ & $3.42(1.02)$ & $3.05(.845)$ & $-3.52 * * *$ \\
\hline $\begin{array}{l}\text { 2. Contracting a disease when giving a blood } \\
\text { donation is highly unlikely. (-) }\end{array}$ & $3.74(.907)$ & $4.04(.906)$ & $3.59(.870)$ & $-4.66 * * *$ \\
\hline $\begin{array}{l}\text { 3. Donating blood can lower my resistance to } \\
\text { colds or infection }(+)\end{array}$ & $2.69(.798)$ & $2.70(.879)$ & $2.69(.754)$ & -.189 \\
\hline $\begin{array}{l}\text { 4. Donating blood can be hazardous to your } \\
\text { health. }(+)\end{array}$ & $2.68(.864)$ & $2.55(.927)$ & $2.75(.822)$ & $-2.13^{*}$ \\
\hline $\begin{array}{l}\text { 5. Mistakes by staff while extracting blood are } \\
\text { highly unlikely. }(-)\end{array}$ & $3.24(.882)$ & $3.18(1.00)$ & $3.26(.815)$ & -.380 \\
\hline $\begin{array}{l}\text { 6. There are potential negative health } \\
\text { consequences of giving a blood donation. }(+)\end{array}$ & $3.17(.844)$ & $3.05(.937)$ & $3.24(.785)$ & -1.28 \\
\hline \multicolumn{5}{|l|}{ Pain and anxiety } \\
\hline 1. Giving blood is not a painful experience. (-) & $3.03(1.06)$ & 3.55 (1.11) & $2.76(.930)$ & $-6.61 * * *$ \\
\hline $\begin{array}{l}\text { 2. Fear of needles and/or of blood draws keeps } \\
\text { people from donating. }(+)\end{array}$ & $4.46(.742)$ & $4.35(.743)$ & $4.52(.737)$ & $-2.48^{*}$ \\
\hline $\begin{array}{l}\text { 3. Giving blood can be an anxiety provoking } \\
\text { experience. }(+)\end{array}$ & $3.77(.969)$ & $3.45(1.11)$ & $3.94(.844)$ & $-3.85^{* * *}$ \\
\hline $\begin{array}{l}\text { 4. The sight of blood is not a major factor } \\
\text { regarding why people do not donate. }(-)\end{array}$ & $2.56(.947)$ & $2.66(.959)$ & $2.50(.938)$ & -1.46 \\
\hline \multicolumn{5}{|l|}{ Time and inconvenience } \\
\hline 1. It is convenient to donate blood. (-) & $3.16(1.01)$ & $3.28(1.12)$ & $3.10(.952)$ & -1.60 \\
\hline 2. Donating blood takes too much time. $(+)$ & $2.49(.842)$ & $2.46(.972)$ & $2.51(.766)$ & -1.22 \\
\hline $\begin{array}{l}\text { 3. Donating blood may get in the way of my } \\
\text { social obligations }(+)\end{array}$ & $2.57(1.05)$ & $2.64(1.18)$ & $2.53(.974)$ & -.489 \\
\hline $\begin{array}{l}\text { 4. Donation collection centers are fast and } \\
\text { efficient with donors }(-)\end{array}$ & $3.40(.759)$ & $3.44(.971)$ & $3.38(.622)$ & -1.54 \\
\hline
\end{tabular}

${ }^{\mathrm{a}}$ Cronbach's alpha $=0.69$

${ }^{\mathrm{b}}$ Differences between donors and non-donors

${ }^{*} p<.05,{ }^{* *} p<.01,{ }^{* * *} p<.001$ 
Table 3. Survey responses for items concerning the perceived generosity of blood donation (5 = strongly agree, 4 = agree, 3 = uncertain, 2 = disagree, 1 = strongly disagree). Mean rank scores, $S D, Z$ statistics (derived from the Wilcoxon-Mann-Whitney Test), and Chi Square values are reported.

\begin{tabular}{|c|c|c|c|c|c|}
\hline \multirow[t]{2}{*}{ Generosity items $^{\mathrm{a}}$} & $\begin{array}{l}\text { All partici- } \\
\text { pants }\end{array}$ & Chi square $^{\mathrm{b}}$ & Donors & $\begin{array}{c}\text { Non- } \\
\text { donors }\end{array}$ & $\begin{array}{l}Z \text { sta- } \\
\text { tistic }^{c}\end{array}$ \\
\hline & $N=346$ & & $N=119$ & $N=227$ & \\
\hline \multicolumn{6}{|l|}{ Perception of donors } \\
\hline $\begin{array}{l}\text { 1. Donating blood is about helping } \\
\text { others. }(+)\end{array}$ & $4.67(.572)$ & $322.24 * * * *$ & $4.64(.607)$ & $4.68(.553)$ & -.587 \\
\hline $\begin{array}{l}\text { 2. Blood donors are not extraordi- } \\
\text { narily generous people. }(-)\end{array}$ & $2.74(1.00)$ & $20.18^{* * * *}$ & $2.77(.961)$ & $2.73(1.03)$ & -.500 \\
\hline 3. Blood donors save lives. $(+)$ & $4.65(.530)$ & $335.00 * * * *$ & $4.66(.528)$ & $4.64(.533)$ & -.209 \\
\hline $\begin{array}{l}\text { 4. It takes an unselfish person to } \\
\text { donate blood. }(+)\end{array}$ & $3.06(1.04)$ & 0.90 & $3.01(1.05)$ & $3.09(1.04)$ & -.815 \\
\hline $\begin{array}{l}\text { 5. Blood donors are more likely to } \\
\text { share other things in their lives. } \\
(+)\end{array}$ & $3.45(.844)$ & $87.66^{* * * *}$ & $3.59(.858)$ & $3.38(.829)$ & $-2.27 *$ \\
\hline $\begin{array}{l}\text { 6. Giving a donation of blood } \\
\text { sends a message about one's } \\
\text { generosity. }(+)\end{array}$ & $3.50(.918)$ & $79.92 * * * *$ & $3.54(.909)$ & $3.48(.923)$ & -.571 \\
\hline \multicolumn{6}{|l|}{ Perception of need for blood } \\
\hline 1. The need for blood is great. $(+)$ & $4.38(.749)$ & $286.40^{* * * *}$ & $4.35(.829)$ & $4.39(.704)$ & -.038 \\
\hline $\begin{array}{l}\text { 2. I will never need a blood trans- } \\
\text { fusion. (-) }\end{array}$ & $2.60(.752)$ & $82.28 * * * *$ & $2.50(.791)$ & $2.65(.727)$ & -1.48 \\
\hline $\begin{array}{l}\text { 3. There is not a pressing need for } \\
\text { blood donors at this point in } \\
\text { time. (-) }\end{array}$ & $1.91(.784)$ & $248.12 * * * *$ & $1.82(.860)$ & $1.96(.739)$ & $-2.02 *$ \\
\hline $\begin{array}{l}\text { 4. If the current rate of donations } \\
\text { does not increase, we will con- } \\
\text { tinue to have insufficient blood } \\
\text { supplies. }(+)\end{array}$ & $3.71(.760)$ & $172.08 * * * *$ & $3.77(.838)$ & $3.68(.715)$ & -.908 \\
\hline
\end{tabular}

${ }^{\text {a }}$ Cronbach's alpha $=0.62$

${ }^{\mathrm{b}}$ Chi square test of proportions (predicted proportion of 0.5 ) comparing ratio of agree:disagree responses.

${ }^{\mathrm{c}}$ Differences between donors and non-donors

$* p<.05, * * * * p<.0001$ 
Table 4. Survey responses for items concerning the perceived health status of donors ( $5=$ strongly agree, 4 = agree, 3 = uncertain, 2 = disagree, 1 = strongly disagree). Mean rank scores, $S D, Z$ statistics (derived from the Wilcoxon-Mann-Whitney Test, and Chi Square values are are reported

\begin{tabular}{|c|c|c|c|c|c|}
\hline \multirow[t]{2}{*}{ Health status signal items ${ }^{\mathrm{a}}$} & $\begin{array}{l}\text { All partici- } \\
\text { pants }\end{array}$ & Chi square $^{b}$ & Donors & $\begin{array}{l}\text { Non- } \\
\text { donors }\end{array}$ & $\begin{array}{c}Z \\
\text { statistic }^{\mathrm{c}}\end{array}$ \\
\hline & $N=346$ & & $N=119$ & $N=227$ & \\
\hline \multicolumn{6}{|l|}{ Health } \\
\hline $\begin{array}{l}\text { 1. You must be disease-free in } \\
\text { order to donate blood. }(+)\end{array}$ & $4.43(.793)$ & $276.16^{* * * *}$ & $4.31(.963)$ & $4.49(.681)$ & -1.05 \\
\hline $\begin{array}{l}\text { 2. One does not need to be } \\
\text { physically fit to give blood. (-) }\end{array}$ & $3.23(.943)$ & $19.12^{* * * *}$ & $3.30(.996)$ & $3.19(.914)$ & -1.12 \\
\hline $\begin{array}{l}\text { 3. Those in poor health can } \\
\text { donate blood. (-) }\end{array}$ & $2.29(.808)$ & $154.74 * * * *$ & $2.25(.904)$ & $2.31(.754)$ & -.723 \\
\hline $\begin{array}{l}\text { 4. Blood donations are less risky } \\
\text { for those of good health }(+)\end{array}$ & $3.82(.743)$ & $200.60 * * * *$ & $3.92(.696)$ & $3.78(.763)$ & -1.68 \\
\hline
\end{tabular}

${ }^{\mathrm{a}}$ Cronbach's alpha $=0.52,{ }^{\mathrm{b}}$ Chi square test of proportions (predicted proportion of 0.5 ) comparing ratio of agree:disagree responses. ${ }^{\mathrm{C}}$ Differences between donors and non-donors $* * * * p<.0001$
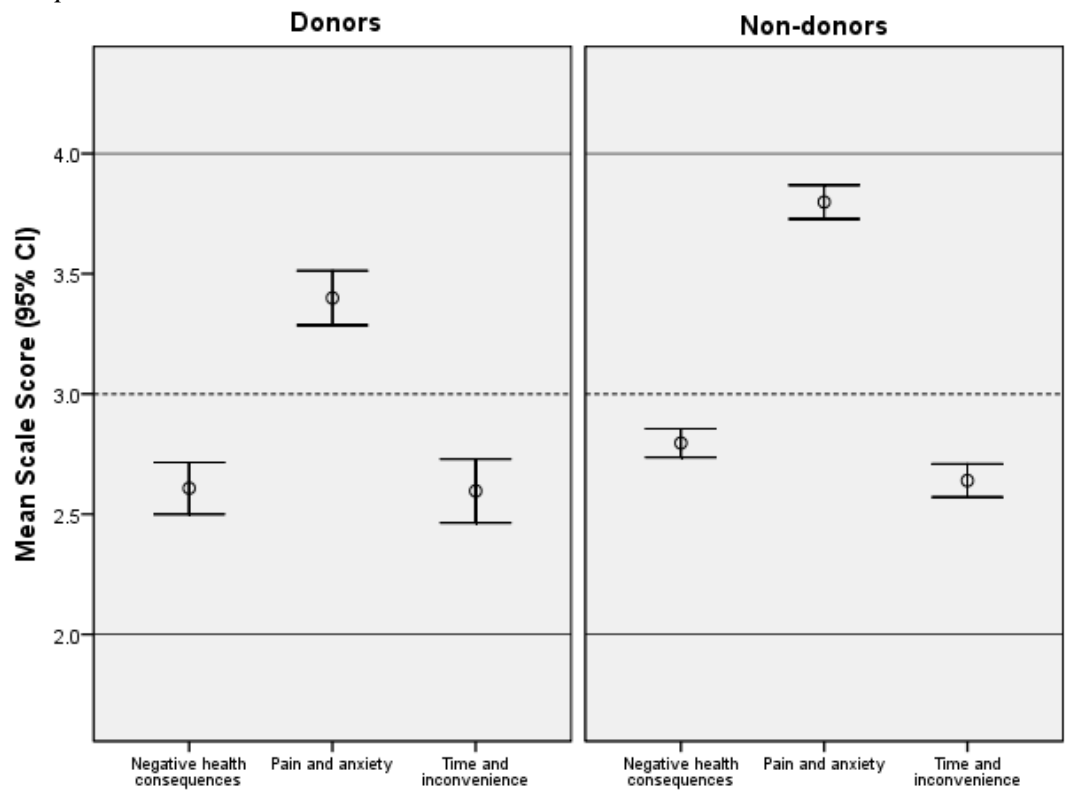

Fig. 1. Item cluster means and 95\% confidence intervals derived from a 5-point Likert scale ( 5 = strongly agree, 4 = agree, 3 = uncertain, 2 = disagree, 1 = strongly disagree). See Table 2 for items included in this analysis. The means for reversed Likert items (-) were corrected prior to analysis. Negative health consequence: donors, item cluster mean 2.60, 95\% CI 2.50-2.71, $n=119$; non-donors, item cluster mean 2.80, 95\% CI 2.74-2.86, $n=227$. Pain and Anxiety: donors, item cluster mean 3.40, 95\% CI 3.29-3.51, $n=119$; non-donors, item cluster mean 3.80, 95\% CI 3.73-3.89, $n=227$. Time and inconvenience: donors, item cluster mean 2.60, 95\% CI 2.46-2.73, $n=119$; non-donors, item cluster mean 2.64, 95\% CI 2.57-2.71, $n=227$. 
The item cluster distributions indicate that both donors and non-donors are most concerned about the anticipated pain and anxiety of giving a blood donation, though blood donors are considerably less concerned than non-donors (Fig. 1). Non-donors are more concerned about the risk of a negative health consequence than donors, while there is little difference regarding the perceived time wasted and inconvenience of giving a blood donation between donors and non-donors (Fig. 1).

\section{Donating blood is perceived as a generous act}

Our prediction that blood donors are perceived as generous and that the need for blood is recognized was supported by the data. All of the items from the "generosity” item cluster (Table 3) received considerably more responses in the predicted direction of the scale, with one exception (Table 3; Perception of donors, item 4).
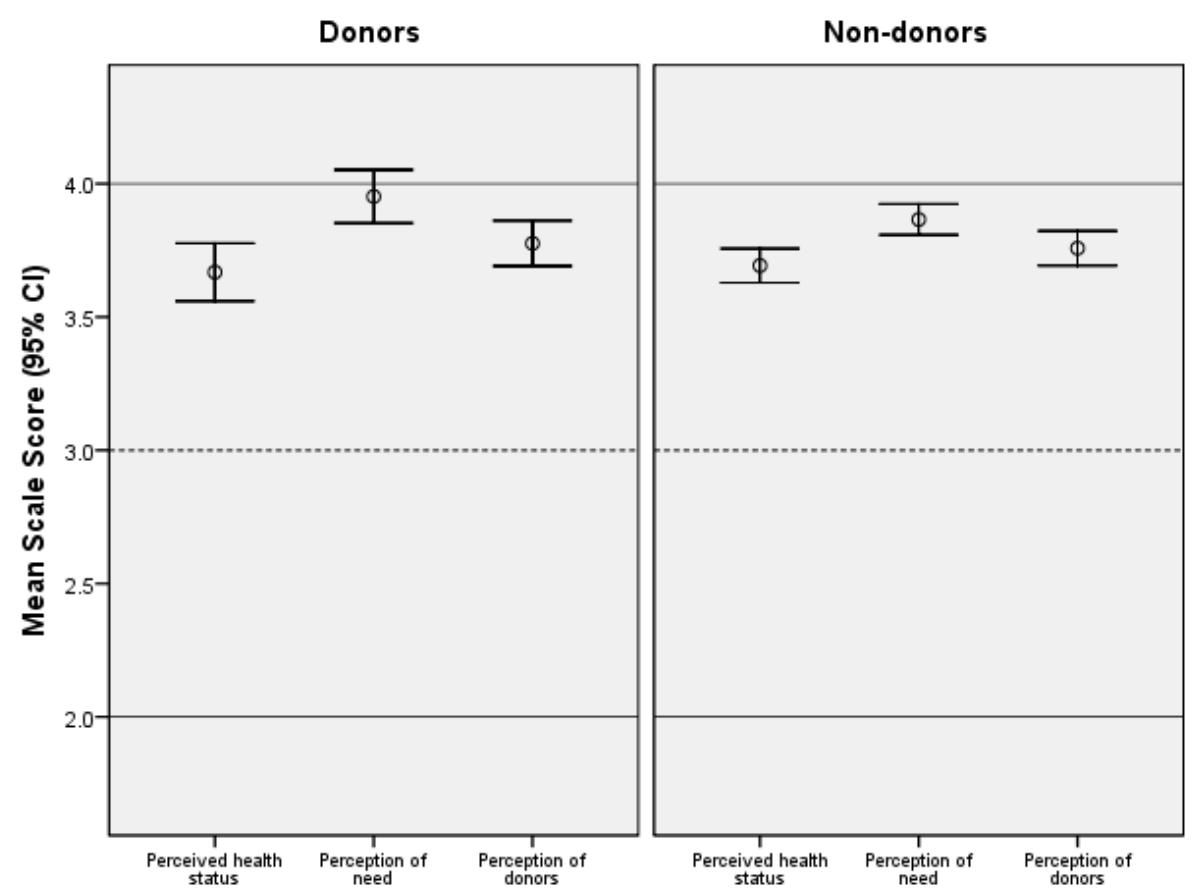

Fig. 2. Item cluster means and $95 \%$ confidence intervals derived from a corrected 5-point Likert scale ( 5 = strongly agree, 4 = agree, 3 = uncertain, 2 = disagree, 1 = strongly disagree). See Tables 3 and 4 for items included in this analysis. The means for reversed Likert items (-) were corrected prior to analysis. Perceived health status: donors, item cluster mean 3.67, 95\% CI 3.56-3.78, $n=119$; non-donors, item cluster mean 3.69, 95\% CI 3.63-3.76, $n=227$. Perception of need: donors, item cluster mean 3.95, 95\% CI 3.85-4.05, $n=119$; non-donors, item cluster mean 3.87, 95\% CI 3.81-3.92, $n=227$. Perception of donors: donors, item cluster mean 3.78, 95\% CI

3.69-3.86, $n=119$; non-donors, item cluster mean 3.76, 95\% CI 3.69-3.82, $n=227$. 
Each item from the "need" item cluster also received considerably more responses in the predicted direction of the scale (Table 3). Item cluster distributions indicate that blood donors are perceived as highly generous and the need for blood is recognized, with very little difference between donors and non-donors in this regard (Fig. 2). Using the method of categorizing Likert responses described earlier we summed the number of "agree" and "disagree" responses in each item cluster and calculated the ratio of "agree" responses to "disagree" responses. One sample chi-square tests with a predicted proportion of 0.5 indicate that the perceived need of blood is great (ratio 909:41; Chi square 791.26; $\mathrm{df}=1 ; p<0.0001$ ), and donors are perceived as generous (ratio 1381:333; Chi square 639.56; $\mathrm{df}=1 ; p<0.0001$ ). Given these results, we conclude that Prediction 3 is supported.

\section{Blood donors are perceived as healthy and disease-free}

We predicted (4) that blood donors are perceived as healthy and disease-free. Each "health status" item (Table 4) received considerably more responses in the predicted direction of the scale with one exception. There was a reverse effect for Item 2, $T a$ ble 4; participants did not feel that blood donors need to be "physically fit" in order to donate (Chi square 19.18; $\mathrm{df}=1 ; p<0.0001$ ). Items cluster distributions clearly demonstrate that blood donors are perceived as healthy and free of diseases, and this perception is shared by donors and non-donors (Fig. 2). Using the method of categorizing Likert responses described earlier we summed the number of "agree" and "disagree" responses in the "Health Status" item cluster and calculated the ratio of "agree" responses to "disagree" responses. A one sample chi-square test with a predicted proportion of 0.5 indicates that donors are perceived as healthy (ratio 915:45; Chi square 786.62; $\mathrm{df}=1 ; p<0.0001$ ). Based on these results, we conclude that prediction 4 is also supported.

\section{DISCUSSION}

\section{The perceived costs of donating blood}

When analyzing human generosity it is important to consider the costs and benefits, both current and future, that influence decisions on whether or not to share (WINTERHALDER and SMITH 2000). Signaling theory makes some rather specific predictions concerning costs and benefits, as outlined earlier in this paper. The signaled information is often related to signal cost in a particular manner, such that greater signal frequency or intensity should indicate a higher-quality signaler who pays lower marginal costs; in addition, others should benefit from obtaining reliable information about signaler quality, and respond in ways that compensates signalers for signal cost. For the present study, we divided the costs of donating blood into 
three categories: (1) anxiety related to pain, needles and the sight of blood, (2) concern about negative health consequences, and (3) inconvenience and time costs.

\section{Anxiety and fear of pain}

By far the greatest perceived cost in our study population is anxiety about needles, pain and the sight of blood (Fig. 1). Fear of the needle was clearly the most anxietyprovoking element of giving a blood donation among our participants, and "negative experiences with the needle" was the most frequently mentioned topic in our open-ended survey item. One respondent reported that intense fear of needles forced her to alter her trek between classes, and wrote "I have a severe fear of needles and I actively avoid even going near the donation truck. Blood donation is something I respect, but I don't think I could ever bring myself to do it.” Our data also indicate that exposure to blood makes many people uncomfortable (Table 2; Anxiety and pain, item 4) and even physically ill. For one of our respondents, "the sight and thought of blood makes me very nauseous and I frequently pass out and/or get dizzy when being vaccinated.” This extreme level of anxiety about giving a blood donation clearly would affect one's willingness to engage in generosity of this nature. Our data show a strong negative relationship between such concerns and a willingness to make a future donation, and this is true for donors as well as nondonors.

Blood donors were significantly less anxious about giving a blood donation than non-donors. Blood donors report less fear of the needle, and less sensitivity to the pain of giving a blood donation (Table 2). What underlying qualities are signaled by blood donors in this regard? Humans oftentimes place themselves in stressful, anxiety-provoking situations that are easily avoidable. This poses an interesting evolutionary problem as it is increasingly clear that anxiety-related stress can result in a suite of negative health outcomes (MCEWEN 1998; SAPOLSKY 2004). Sensitivity to acute and chronic stress is variable (MCEWEN 1998), and knowledge of who can react calmly in high-stress and high-anxiety situations is important information to consider when making decisions about with whom to interact. Preferentially choosing friends, allies, and mates who perform well under pressure is likely to be adaptive in modern and ancestral social environments. Thus, both possessing this quality and gaining information about inter-individual variation in this quality may have adaptive value, and provide a selective advantage for honest communication via costly signaling. Of course, it is also adaptive to be anxious about sharp objects penetrating one's body. The tradeoff between these two sets of attitudes will arrive at different preferences and outcomes between different individuals, and selection may well favor an equilibrium mix of risk-takers and riskavoiders rather than some optimum that applies to all in the population. The logic of this aspect of our signaling hypothesis is simply that judicious risk-taking and will- 
ingness to endure pain in the interests of socially-beneficial outcomes may increase one's value as an ally in various contexts.

We considered the possibility that blood donors may have less fear because of their past experiences donating blood. Our data do not indicate that perceived anxiety decreases as donation frequency increases beyond a single instance. It is also important to note that we found a negative relationship between anxiety/fear and the likelihood of giving a future donation among both donors and non-donors, again demonstrating that anxiety/fear affects the willingness to donate even for those who have given blood.

\section{Concern over negative health consequences}

Research across cultures indicates that prospective blood donors are concerned about the possibility of negative health outcomes (ALLEN and BUTLER 1993; Hosain, ANisSuZzam and Begum 1997; HuPfer, Olaiya et al. 2004; TAYLOR and LETWIN 2005). While our research indicates a strong association between the perceived risk of a negative health consequence and the likelihood of future donation, the overall perceived risk in this regard was relatively low. One reason for this may be that our respondents were not raised in the social climate of the 1980s when a general fear of contracting HIV via blood transfusions and needles was prevalent. Some respondents were concerned about the risk of contracting a disease and other negative health consequences, and several shared their "horror" stories about recurring fainting spells, vomiting, and experiencing weakness for several days after giving a blood donation. Major phlebotomy-related donation complications are considerably higher for donors that are 18-19 years of age compared with donors who are over the age of 20 years (EDER et al. 2008), indicating that our study population is indeed at high relative risk. Blood donors in our study are significantly less concerned than non-donors about the risk of a negative health consequence. These stated attitudes may reflect bravado (a false signal) rather than honest information about their anxieties; they might indicate that donors are indeed more willing to endure costs for a common good; or they might indicate that donors have been subject to more pressure to donate. Future research should test these alternative hypotheses using experimental and/or ethnographic research.

\section{Time and inconvenience}

As mentioned, wasting time is another type of uneconomical behavior that can send information about one's economic status and trustworthiness (VEBLEN 1899; BERGSTROM, KERR and LACHMANN 2008). Information of this nature is not easily observable, but could be valuable when making decisions about how to interact with a person. Spending time giving a blood donation that could be used for other fitness-enhancing activities may send a reliable message about an individual's eco- 
nomic standing. Donating blood is by no means a fast and convenient process. In discussions with blood donors, one of us found that the extraction process combined with travel time and paperwork can take 2 or more hours. It is not surprising that time wasted and inconvenience has been shown to deter prospective donors from donating blood (SCHREIBER et al. 2006).

The differences between non-donors and donors regarding the time wasted and inconvenience of giving a blood donation were negligible. Overall, time costs and inconvenience were not seen as significant, and did not affect a willingness to give a future donation (Table 2; Fig. 1). This may be due to the convenience of donating blood for those in our sample. Blood donations at UW, Seattle are principally collected in "blood buses" (mobile blood collection units) in a central area of the main campus. In addition to their conspicuous presence and accessibility, the buses collect blood several times a month. Of those in our sample that had donated blood at least once, $57 \%$ had donated at the UW or another college campus. Thus, the time costs and inconvenience of giving a blood donation are relatively lower for our study population than they might be in a non-college sample.

Because participants in our sample were less sensitive to the costs of donating compared with the general public, it is not surprising that our sample contained an unusually large proportion of donors (34\%) compared with current frequencies of donors in the U.S. (5\%) (GLYNN et al. 2006). Fortunately for blood donation recruiters, if our data are representative of college students in the U.S., two important deterrents - fear of contracting diseases and time wasted/inconvenience - may be receding with time.

\section{Signaling Generosity and Cooperative intent}

We have discussed the types of information that may be signaled by donating blood in terms of costs, and will now consider the "altruistic message" that may also be conveyed by blood-sharing behavior. In a social environment where nonreciprocators are ubiquitous, a necessary condition for the success of cooperators is that they can positively assort. Honest communication in the form of costly acts of generosity, such as making a blood donation, can help to achieve this goal. In addition to their value as reliable reciprocators, altruists have also been shown to be more appealing to the opposite sex and able to attract high quality partners (HAWKeS, O'CONNELl and BluRTON JONES 2001; Kelly and DunBar 2001; SMITH, BLIEGE BIRD and BIRD 2003; FARRELLY, LAZARUS and ROBERTS 2007).

The effectiveness of a signal is dependent on the attentiveness of the audience. Is the need for donors and blood recognized? The need for blood and blood donors is critical; less than $5 \%$ of the American population donates blood, and the number of units of blood collected has dropped in recent years despite increasing need (SANCHEZ et al. 2001; BOULWARE et al. 2002; HUPFER, TAYLOR and LETWIN 2005; GLYNN et al. 2006). Our data indicate that both donors and non-donors agree that 
there is a "pressing" need for blood donors and that the need for blood is "great" (Table 3; Fig. 2). It is possible that simply taking part in the study raised the awareness regarding the need for blood, but we feel this had only a negligible effect on the results. A high proportion of respondents realize that they, or someone they know, may be saved by a blood transfusion. In our sample of young adults, $41 \%$ report knowing a person who has received a blood transfusion and $51 \%$ believe that they will need a blood transfusion at some time in their life; there are no differences between donors and non-donors in this regard. Thus, it is not surprising that our respondents felt strongly that blood donors "save lives" and that giving a blood donation is about "helping others" (Table 3).

Based on our data, we feel that a blood donation may be interpreted as signaling an individual's willingness and capacity for generosity. We explored this proposition by including two items in our generosity item cluster that specifically approached whether or not blood donation is perceived as a reliable signal of generosity in other domains (Table 3; Perception of donors, items 5 and 6). Respondents felt that donors were "more likely to share other things in their life" and that a blood donation "sends a message about one's generosity" (Table 3). This is consistent with past research which indicates that blood donors are more likely to volunteer in other social venues, exhibit a greater desire for self-sacrifice, and are less likely to have free-riding tendencies (CONDIE et al. 1976; BOE and PONDER 1981; PILIAVIN and CALLERO 1991). Our initial finding that donors are perceived to be reciprocators is particularly amenable to future testing using a game method.

\section{Blood donations as a signal of health quality}

Many prospective donors, about $40 \%$ in the U.S., are ineligible to donate blood for reasons such as health problems and disease status (GLYNN et al. 2006). In addition, people who engage in risky sexual behavior or inject illegal drugs can be ineligible; and those that have traveled in areas with a high prevalence of diseases are also barred from donating. Over 32\% of our survey participants had tried to give blood but were ineligible at the time. They cited a variety of reasons for being turned down: undisclosed infections, insufficient body weight, medications, anemia, highrisk sexual behavior, vasovagal syncope, recent tattoos or piercings, diabetes, foreign travel, "tiny veins", thyroid disorder, hemophilia, and low blood pressure. Demonstrably free from potential health issues, individuals who are eligible to donate blood are able to convey reliable information regarding health, disease status, and physical vitality to potential mates or prospective long-term partners. Long-term, repeat donors can maintain their "health reputation" by providing current information about health status.

But do people know about the aforementioned eligibility criteria and see blood donors as healthy and disease-free? Our study indicates that both donors and nondonors do. Respondents felt strongly that a donor must be "disease-free" in order to 
donate and that those in poor health are ineligible (Table 4). As mentioned above, prospective and current donors fear a range of negative health consequences (OlAiYA et al. 2004; HuPfER, TAYLOR and LETwin 2005). Those who donate blood regularly may be risking these negative outcomes as a means to signal vitality and physical prowess. Lending support to this proposition, respondents felt that a blood donation is "less risky" for those of good health (Table 4).

\section{How are the signals conveyed?}

While we have demonstrated that giving a blood donation can plausibly be interpreted as a costly signal of donor quality, we have not discussed possible mechanisms by which the signal is conveyed. Blood donors are often offered gifts, such as T-shirts and lapel pins that are of little material value. However, these gifts have one thing in common: they include statements that identify donor status, such as "I saved a life, I donated blood." Blood buses and Centers in the Seattle area offer these incentives, as well as a choice of several brightly colored bandages and even fluorescent tourniquets to cover the needle site. This highly observable symbol invites onlookers to ask "What happened to you?" and may enhance signal transmission and reliability.

A problem with blood donation as a medium for honest signaling is the potential for fakery; for example, one could wear a "I donated blood" shirt without actually making a donation. However, the social arenas in which donors are signaling may make defecting difficult. We propose that blood donors are signaling to members of their active social network. Falsely claiming donor status to friends and peers would be difficult to accomplish, and would be reputationally risky.

\section{CONCLUSION}

Explaining human altruism is a complex challenge that is likely to have a variety of answers. Costly signaling theory is one framework that may contribute to this task. To date, it has received far less attention than some other approaches. However, signaling theory has recently provided insight into unconditional public generosity in both small-scale subsistence societies (GURVEN et al. 2000; SMITH and BLIEGE BIRD 2000) and industrialized ones (SOSIS 2006; BARCLAY and WILLER 2007; LYLE and Sullivan 2007; BereCZKEI, BirKAS, and KereKes 2007; NELISSEN 2008; OHSTUBO and WATANABE 2009). In this paper we have begun the task of evaluating its promise for explaining altruistic behavior in the blood donation context by analyzing attitudes about health and injury risks, donor characteristics, and the social value of blood donations in a sample of young adults. Because only a minority of people donate blood, and the benefits of blood transfusion are available to those who need them regardless of their past or future donation activity, unremu- 
nerated blood donations provide an ideal context for testing theories of human altruism that extend beyond conditional reciprocity.

Our findings, based as they are on survey data, cannot answer questions about the current adaptiveness of blood donation. As noted in the introduction, some might interpret unconditional generosity (such as blood donation) as a product of psychological mechanisms that evolved in a world where there were no strangers and individuals' actions were known to all members of their society. On the other hand, some of the ethnographic particulars reviewed above suggest that relevant members of one's social group will be aware of such acts even in large urban settings, and indeed that aspects of blood donation are designed to transmit such information effectively and reliably. Only future research can decide such issues, but the results reported here are not affected by this larger debate over current versus past adaptiveness.

This is the first analysis of the phenomenon of blood donations from an evolutionary perspective. Our initial research provides the groundwork for subsequent research, and suggests several directions for observational and experimental approaches to further examine if the full set of conditions for a costly-signaling dynamic (MAYNARD SMITH and HARPER 2003; BliEge BIRD and SMITH 2005) are met in the case of blood donation. First, it would be desirable to collect observational data on actual social consequences of blood donation in this and other study populations. Second, our results indicate that willingness to share and other attributes of blood donors should be tested experimentally as well as ethnographically. It should also be noted that our sample was limited to young adults in a college setting, and may not be representative of the broader population. Most of the blood donors in our student sample had donated once only, and important insights may be obtained by analyzing repeat donors as a distinct group in future research. Finally, gender differences in blood donor motivation should also be considered in future research.

\section{ACKNOWLEDGEMENTS}

We would like to thank several anonymous reviewers and Richard Sosis, Ed Hagen, Wesley Allen-Arave and Donna Leonetti for helpful comments on earlier drafts.

\section{REFERENCES}

Allen, J. \& Butler, D. D. (1993): Assessing the effects of donor knowledge and perceived risk on intentions to donate blood. Journal of Health Care Marketing, 13, 26-33.

AndroulaKi, Z., Merkouris, A., Tsouras, C. \& ANDroulaKis. M. (2005): Knowledge and attitude towards voluntary blood donation among a sample of students in Tei of Crete, Greece. ICUS and Nursing Web Journal, 23, 1-9. 
Barclay, P. \& WiLleR, R. (2007): Partner choice creates competitive altruism in humans. Proceedings of the Royal Society of London Series B, 274, 749-753.

BereczKeI, T. Birkas, B. \& KereKes, Z. (2007): Public charity offer as a proximate factor of evolved reputation-building strategy: an experimental analysis of a real-life situation. Evolution and Human Behavior, 28, 277-284.

Bergstrom, C.T., Kerr, B. \& Lachmann, M. (2008): Building trust by wasting time. In: Zak, P. (ed): Moral Markets: The Critical Role of Values in the Economy pp. (142-156). Princeton University Press.

BliEgE BiRD, R.L. \& SMith, E.A. (2005): Signaling theory, strategic interaction, and symbolic capital. Current Anthropology, 46, 221-248.

BoE, G.P. \& Ponder, L.D. (1981): Blood donors and non-donors: a review of research. American Journal of Medical Technology, 47, 248-253.

Boone, J. (1998): The evolution of magnanimity: When is it better to give than to receive? $\mathrm{Hu}-$ man Nature, 9, 1-21.

Boulware, L.E., Ratner, L.E., Ness, P.M., CoOper, L.A., CAmpBell-LeE, S., LaVeist, T.A. \& PowE, N.R. (2002): The contribution of sociodemographic, medical, and attitudinal factors to blood donation among the general public. Transfusion, 42, 669-678.

Byrne, J.P., Miller, D. \& SCHAFER, W.D. (1999): Gender differences in risk-taking: A metaanalysis. Psychological Bulletin, 125, 367-383.

CONDIE, S.J., WARNER, W.K. \& GiLlman, D.C. (1976): Getting blood from collective turnips: volunteer donation in mass blood drives. Journal of Applied Psychology, 61, 290-294.

DAly, M., \& Wilson, M. (2001): Risk-taking, intrasexual competition, and homicide. In: French, J.A., Kamil, A. C. Leger, D. W. (eds.): Evolutionary Psychology and Motivation (pp. 1-36). Lincoln: University of Nebraska Press.

Dawkins, R. (1976): The Selfish Gene. Oxford University Press.

Eder, A.F., Hillyer, C., Dy, B.A, Notari, E.P. \& BenJamin, R.J. (2008): Adverse reactions to allogeneic whole blood donation by 16- and 17-year-olds. Journal of the American Medical Association, 299, 2279-2286.

FARRELly, D., LAZARUS, J. \& RoBERTS, G. (2007): Altruists attract. Evolutionary Psychology, 5, 313-329.

FARTHING, G.W. (2005): Attitudes towards heroic and non-heroic physical risk takers as mates and friends. Evolution and Human Behavior, 26, 205-214.

FERnANDEZ-Montoya, A. (1997): Altruism and payment in blood donation. Transfusion Science, 18, 379-386.

GETTY, T. (2002): Signaling health versus parasites. American Naturalist, 159, 363-371.

GinTIS, H., SMith, E.A. \& BowLES, S.L. (2001): Cooperation and costly signaling. Journal of Theoretical Biology, 213, 103-119.

Glynn, S., Kleinman, S., Schreiber, G., Zuck, T., McCombs, S. et al. (2002): Motivations to donate blood: demographic comparisons. Transfusion 42: 216-225.

Glynn, S., Schreiber, G., Murphy, E., Kessler, D., Higgens, M. et al. (2006): Factors influencing the decision to donate: racial and ethnic comparisons. Transfusion, 46, 980-990.

Grafen, A. (1990): Biological signals as handicaps. Journal of Theoretical Biology, 144, 517-546.

Gurven, G., Allen-Arave, W., Hill, K. \& Hurtado, M. (2000): “It’s a wonderful life:” Signaling generosity among the Ache of Paraguay. Evolution and Human Behavior, 21, 263-282.

Hawkes, K., O’Connell, J.F. \& BluRton Jones, N.G. (2001): Hadza Meat Sharing. Evolution and Human Behavior, 22, 113-142.

HAWKES, K. \& BLIEGE BIRD, R.L. (2002): Showing off, handicap signaling, and the evolution of men's work. Evolutionary Anthropology, 11, 58-67. 
Hosain, G.M., Anissuzzam, M. \& Begum, A. (1997): Knowledge and attitude towards voluntary blood donation among Dhaka University students in Bangladesh. East African Medical Journal, 74, 549-553.

Hupfer, M.E., TAYLOR, D.W. \& Letwin, J.A. (2005): Understanding Canadian student motivations and beliefs about giving blood. Transfusion, 45, 149-161.

HuPFER, M.A. (2006): Helping me, helping you: self-referencing and gender roles in donor advertising. Transfusion, 46, 996-1005

Johnstone, R. A. (1997): The evolution of animal signals. In: Krebs J. R., Davies N. B. (eds.): Behavioural ecology: an evolutionary approach (pp. 155-178). Oxford: Blackwell.

Kelly, S., \& DunBaR, R.I. (2001): Who dares, wins: Heroism versus altruism in women's mate choice. Human Nature, 12, 89-105.

Loyau, A., Jaime, M.S., Cagniant, C. \& Sorci, G. (2005): Multiple sexual advertisements honestly reflect health status in peacocks (Pavo cristatus). Behavioral Ecology and Sociobiology, 58, 552-557.

LyLE III, H.F. \& SulLIVAN R.J. (2007): Competitive status signaling in peer-to-peer file-sharing networks. Evolutionary Psychology, 5, 363-382.

Maynard SMith, J. \& HARPER, D. (2003): Animal signals. Oxford: Oxford U. Press.

McEwEN, B.S. (1998): Protective and damaging effects of stress mediators. New England Journal of Medicine, 338, 171-179.

Milinski, M., Semmann, D. \& Krambeck, H. (2002): Donors to charity gain in both indirect reciprocity and political reputation. Proceedings of the Royal Society of London, Series B, 269, 881-883.

NELL, V. (2002): Why young men drive dangerously: implications for injury prevention. Current Directions in Psychological Sciences, 11, 79-82.

NELISSEN, R. A. (2008): The price you pay: cost-dependent reputation effects of altruistic punishment. Evolution and Human Behavior, 29:242-248.

Ohtsubo, Y. \& WATANABE, E. (2009): Do sincere apologies need to be costly? Test of a costly signaling model of apology. Evolution and Human Behavior, 30:114-123.

OlaiYa, M.A., AlakiJa, W., Ajala, A. \& Olatunji, R.O. (2004): Knowledge, attitudes, beliefs and motivation toward blood donation among blood donors in Lagos, Nigeria. Transfusion Medicine, 14, 13-17.

Piliavin, J.A. \& CAllero, P.L. (1991): Giving Blood: The Development of an Altruistic Identity. Johns Hopkins University Press.

RAPPORT, F.L. \& Maggs, C.J. (2002): Titmuss and the gift relationship: altruism revisited. Journal of Advanced Nursing, 40, 495-503.

RoBerTs, G. (1998): Competitive altruism: From reciprocity to the handicap principle. Proceedings of the Royal Society of London, 265, 427-431.

Robertson, B.J. \& McQueEn, D.V. (1994): Perceived risk of becoming infected with HIV by donating and changes in reported blood donation practice among the Scottish general public 1989-92. AIDS-Care, 6, 435-442.

Sanchez, A., Ameti, D., Schreiber, G., Thomson, R., Lo, A. et al. (2001): The potential impact of incentives on future blood donation behavior. Transfusion, 4, 172-178.

SAPOLSKY, R.M. (2004): Social status and health in humans and other animals. Annual Review of Anthropology, 33, 393-418.

Schreiber, G.B., SclumpF, K.S., Glynn, S.A., Wright, D.J., Tu, Y. et al. (2006): Convenience, the bane of our existence, and other barriers to donating. Transfusion, 46, 545-553.

SMith, E.A. \& BliEge BIRD, R.L. (2000): Turtle hunting and tombstone opening: Public generosity as costly signaling. Evolution and Human Behavior, 21, 245-261.

SMith, E.A., BLIEgE BiRD, R.L. \& BIRD, D. (2003): The benefits of costly signaling: Meriam turtle hunters. Behavioral Ecology, 14, 116-126. 
SMith, E.A. \& BLIEgE BIRD, R.L. (2005): Costly signaling and cooperative behavior. In: Gintis, H., Bowles, S., Boyd, R., Fehr, E. (eds.): Moral sentiments and material interests: On the foundations of cooperation in economic life. Cambridge: MIT Press, pp. 115-148.

Sosis, R. (2000): Costly signaling and torch fishing on Ifaluk atoll. Evolution and Human Behavior, 21, 223-244.

Sosis, R. (2006): Religious behaviors, badges, and bans: Signaling theory and the evolution of religion. In: McNAMARA. P. (ed.): Where God and Science Meet: How Brain and Evolutionary Studies Alter Our Understanding of Religion, Volume 1: Evolution, Genes, and the Religious Brain. Westport, CT: Praeger Publishers, pp. 61-86.

SPENCE, M. (1973): Job Market Signaling. Quarterly Journal of Economics, 87, 355-374.

TitmusS, R.M. (1971): The gift relationship: From human blood to social policy. New York: Random House

VeBLEN, T. (1899): The theory of the leisure class. New York: Dover.

Waitt, C.A., Little, C., Wolfensohn, S., Honess, P., Brown, A.P. et al. (2003): Evidence from Rhesus macaques suggests that male coloration plays a role in female primate mate choice. Proceedings of the Royal Society of London, Supplement: Biology Letters, S144S146.

Wilke, A., Hutchinson, J.M., TodD, P.M. \& KRUGER, D.J. (2006): Is risk taking used as a cue in mate choice? Evolutionary Psychology, 4, 367-393.

Wilson, M. \& DALY, M. (1985): Competitiveness, risk-taking, and violence: the young male syndrome. Ethology and Sociobiology, 6, 59-73.

Winterhalder, B. \& SMith, E.A. (2000): Analyzing adaptive strategies: Human behavioral ecology at twenty-five. Evolutionary Anthropology, 9, 51-72.

WiWANITKIT, V. (2002): Knowledge about blood donation among a sample of Thai university students. Vox Sanguinis, 83, 97-99.

ZAHAVI, A. (1975): Mate selection - a selection for handicap. Journal of Theoretical Biology, 53, 205-214.

ZahAVi AmotZ, \& Avishag ZAHAVI (1997): The handicap principle: A missing piece of Darwin's puzzle. Oxford University Press. 